Dept. of Clinical Studies,

Fac. of Vet. Science, University of Nyala, Sudan.

\title{
EFFECT OF THIOPENTONE SODIUM ON SOME PHYSIOLOGICAL AND ANAESTHETIC PARAMETERS IN DESERT GOATS
}

(With 4 Tables)

\section{By}

\author{
M.A.H. GHURASHI; A.T.H. SOBAIR*; \\ ASHWAG E.A.M.** and H.I. SERI \\ *Dept. of Surgery and Anaesthesia, Fac. of Vet. Med., \\ University of Khartoum Sudan.
}

** Dept. of Physiology and Biochemistry, Fac. of Vet. Science, University of Nyala, Sudan.

(Received at 10/2/2008)

\section{تأثير عقار الثيوينتون صوديوم علي بعض القياسات التخديرية و الفسيولوجية

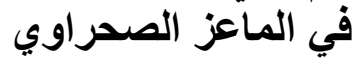

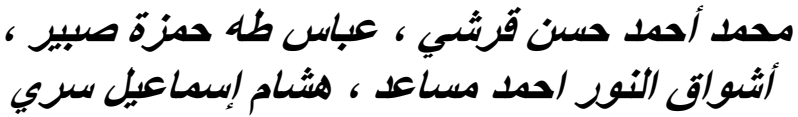

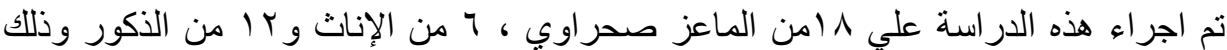



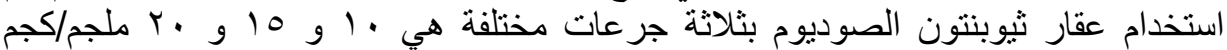

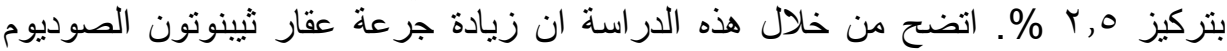



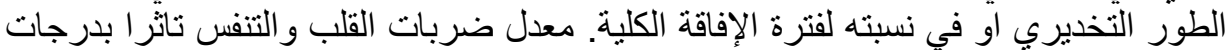

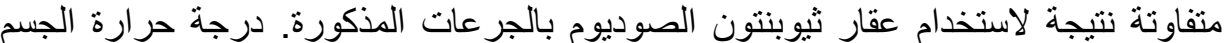



\section{SUMMARY}

This study was conducted using 18 clinically healthy desert goats (6 females and 12 males) to study the effect of increasing the dose of Thiopentone sodium on some physiological and anaesthetic parameters. Thiopentone sodium was used at three different dose levels $(10,15$ and $20 \mathrm{mg} / \mathrm{kg}$ body weight) $2.5 \%$ solution. Increasing the dose of Thiopentone sodium resulted in an increase in the duration of the 
different anaesthetic phases. This increase might be in terms of duration of the phase or percentage of the phase to the total recovery time. Respiration and heart rate were affected significantly $(\mathrm{P}<0.05)$ as a result of using Thiopentone sodium at the three different levels. Rectal temperature was affected non- significantly in the three groups.

Key words: Anathesia, thiopentone sodium, goats

\section{INTRODUCTION}

Goats participate efficiently in the economy of the third world countries through production of meat, milk and skin (Pandy, 1994). Sometimes goats face some health problems that need surgical interference which might be carried out under general anaesthesia.

Thiopentone sodium is a monosodium salts of 5- ethyl -5 - (1methylbutyl) -2- thiobarbiturate (100 parts $\mathrm{w} / \mathrm{w}$ ) and exsiccated sodium carbonate (6 parts w/w) (Vickers et al., 1984). Thiopentone sodium can be used in different dose levels to serve different functions like induction or maintenance of anaesthesia. The different effects of Thiopentone sodium on the patient like induction time, duration of anaesthesia and total recovery time are governed by many factors including the dose, concentration and speed of injection.

This study is aimed to detect the effect of changing the dose of Thiopentone sodium on some anaesthetic phases and physiological parameters in non premedicated goats.

\section{MATERIALS and METHODS}

\section{Animals:}

A total of 18 healthy desert goats (6 females and 12 males), the age of the animals varying between 12-18 months, were used in this study. They were mature desert goats weighing between 18 to 25 kilograms. They were kept in closed pens and fed with roughages and concentrates with free access to water during the period of the experiment. The animals were kept for two weeks before starting experiment to be adapted to the environment

\section{Protocols of anaesthesia used:}

The animals were divided randomly into three groups $\mathrm{A}, \mathrm{B}$ and C. The animals in the three groups $\mathrm{A}, \mathrm{B}$ and $\mathrm{C}$ were injected with Thiopentone sodium at dose rate of 10,15 and $20 \mathrm{mg} / \mathrm{kg}$ respectively. 
Thiopentone sodium was used as freshly prepared solution at concentration of $2.5 \%$ and was injected as an intravenous bolus.

\section{Monitoring of the physiological and anaesthetic effects: Physiological effects:}

The respiratory rate, heart rate and rectal temperature were monitored using standard methods according to Kelly (1984).

\section{Anaesthetic effects:}

The study was designed to investigate the following anaesthetic effects:

1- Phases of anaesthesia which include:

- Anaesthesia phase: was taken as the time during which the animal is unconscious, no reflexes and responding negatively to the external stimuli (Tamisto et al., 1981). The external stimuli used in this study were assessment of reflexes and/ or pin brick in the flank region

- Basal narcosis phase: was taken as the duration in which the animal showed signs of unconsciousness but responding positively to external stimuli (Atkinson et al., 1987, Hall and Clark 1982), the external stimuli used in this study were assessment of reflexes and/ or pin brick in the flank region

- Lateral recumbancy phase: was monitored subjectively and taken as the phase during which the animal opened its eyes and the reflexes were regained but it is unable to adopt sternal recumbancy position.

- Sternal recumbancy phase: was taken subjectively as the time elapse during which the animal adopted sternal position but unable to stand.

- Standing phase: Was taken as the time during which the animal succeeded to adopt standing position but unable to walk for ten steps without falling.

- Recovery: The animal was considered to be recovered from anaesthesia when it was able to support its self in the standing position and was able to walk for ten steps with out falling.

\section{Statistical analysis:}

The data concerning respiratory rate, heart rate and rectal temperature were analyzed using one way ANOVA and considering the base line value as a control within the same group. The different phases of anaesthesia were compared with each other using one way ANOVA. The least significant difference was used to determine the significance. 


\section{RESULTS}

Comparison of the anaesthetic phase in the different treated groups revealed a significant difference $(\mathrm{P} \leq 0.05)$ between the three groups tested as shown in table (1). Duration of the narcosis phase was found to be of a significant difference $(\mathrm{P} \leq 0.05)$ between group $\mathrm{A}$ and group $\mathrm{B}$, while the difference between group $\mathrm{B}$ and group $\mathrm{C}$ was found to of a non significant value $(\mathrm{P} \geq 0.05)$ as shown in Table (1). The duration of the lateral recumbancy phase in the three groups tested revealed no significant differences $(P \geq 0.05)$ as shown in Table (1). Comparison of the duration of the sternal recumbancy phase in the three groups tested showed non significant difference $(P \geq 0.05)$ as shown in Table (1). In the three groups under investigation the duration of the standing time phase was found to be of a non significant difference $(\mathrm{P} \geq 0.05)$ as shown in Table (1). Group A showed a significantly $(\mathrm{P} \leq 0.05)$ shorter duration of total recovery time, while the difference in the duration of this phase was found to be of a non significant difference $(\mathrm{P} \geq 0.05)$ between group $\mathrm{B}$ and group $\mathrm{C}$ as shown in Table (1).

\section{Physiological changes}

In group $(A)$ significant increase $(\mathrm{P} \leq 0.05)$ in respiratory rate was observed at 20min, after induction of anaesthesia while in group B significant increase $(\mathrm{P} \leq 0.05)$ in respiratory rate was occurred at 40 and 50 minutes after induction of anaesthesia. In group $\mathrm{C}$ significant drop $(\mathrm{P} \leq 0.05)$ in the respiratory rate occurred immediately after induction of anaesthesia and persisted at significantly high levels until 30 minutes after induction of anaesthesia as shown in Table (2).

An immediate significant increase $(\mathrm{P} \leq 0.05)$ in heart rate was observed in the three groups tested as shown in Table (3). This increase in the heart rate continued for the whole period of anaesthesia in group A, while in group B it observed again at 10,20,30 and 40 minutes after induction of anaesthesia. In group $\mathrm{C}$ in addition to the immediate tachycardia mentioned above a significant increase $(\mathrm{P} \leq 0.05)$ in the heart rate was occurred also at 40 minutes after induction of anaesthesia.

Non significant change $(\mathrm{P} \geq 0.05)$ in rectal temperature was observed in the three groups tested as shown in Table (4). 
Assiut Vet. Med. J. Vol. 54 No. 117 April 2008 
Assiut Vet. Med. J. Vol. 54 No. 117 April 2008

एqร 


\section{DISCUSSION}

The significant difference in the duration of the anaesthesia phase observed between group A and group B may be attributed to the factor of increasing the dose of Thiopentone sodium. This finding is supported by the findings of Singh and Kumar (1988). The same justification may be applicable in the case of the significant difference observed in the duration of the narcosis phase between group A and group B.

As reported by Hall and Clark, (1982), Singh and Kumar (1988) the increase in the dose always results in increasing the effect of Thiopentone sodium. These reports are supporting our findings which showed that the increase of Thiopentone sodium dose resulted in an increase in the effect as shown in Table (1).

Although Thiopentone sodium was reported to has a depressing effect on respiratory rate as reported by (Atkinson et al.,1987; and Singh and Kumar 1988; and Taylor, 1990), a significant increase $(\mathrm{P} \leq 0.05)$ in the respiratory rate occurred in group A and group B, this result is not contradictory with the findings reported in the literature because the significant increase in the respiratory rate observed in this study is due to the movements made by the animals during recovery as shown in table (2) where the animals of the two groups reached the phase of sternal recumbancy at the time at which the significant increase $(\mathrm{P} \leq 0.05)$ in the respiratory rate was observed. In group $\mathrm{C}$ a significant drop in respiration was observed immediately after induction of anaesthesia which persisted until 30 minutes after induction of anaesthesia. This finding may be due to the direct depressing effect of Thiopentone sodium on the respiratory centres reported by (Atkinson et al., 1987).

The significant tachycardia $(\mathrm{P} \leq 0.05)$ that occurred immediately in the three treated groups either it is continued for the whole period of anaesthesia as in group A or occurred at different occasions as in group $\mathrm{B}$ or it occurred at the end of the period of anaesthesia, all these findings are supported by the findings of Karimi (1987) and Rawling and Kolata (1983), who reported occurrence of tachycardia during induction of anaesthesia and during intubation subjectively. The findings are supported by the findings of Singh and Kumar (1988) and Kumar and Sharma (1986) who reported occurrence of tachycardia until full recovery was attained.

The non significant effect $(\mathrm{P} \geq 0.05)$ of Thiopentone sodium on rectal temperature observed in our study is supported by the findings of Singh and Kumar (1988) and Kumar and Sharma (1986) who reported the non significant effect of Thiopentone sodium on rectal temperature. 
It may be concluded that the gradual increase in the dose of Thiopentone sodium in goats did not produce the same rate of increase in the parameters tested. However, the increase in dose resulted in significant increase in some of the parameters tested.

\section{REFERENCES}

Atkinson, R.S.; Rashman, G.B. and Alfred lee, J. (1987): A synopsis of anaesthesia. $10^{\text {th }}$ ed. Wright, Bristol, London.

Hall, L.W. and Clark, K.W. (1982): Veterinary anaesthesia, $8^{\text {th }}$ edition. ELSB and Bailliere and Tindal. London pp. 51-283.

Jani, B.M.; Patel, G.R.; and Manari, M.N. (1982): Evaluation of propandid in combination with different preanaesthetic agents in dogs. Indian Veterinary Journal, 59: 773-776.

Karimi, A. (1987): Comparison of the effect of two sets of anaesthetic agents and posture on respiratory rate, heart rate $\mathrm{pH}$, blood gas and acid base balance in horse. British Veterinary journal. 143(6): 506-512

Kelly, W.R. (1984): Veterinary Clinical Diagnosis. $3^{\text {rd }}$ ed. Bailliere and Tindal, London. Pp $22-40$

Kumar, A.; and Sharma, A.K. (1986): Thiopentone with and without Xylazine premedication in buffaloes. Indian Journal of Animal Science.56(10):1022-1029

Pandy, W.J.A. (1994): An introduction to animal husbandry in the tropics. $4^{\text {th }}$ edition. Longman Group. Longman House Burnt Mill, Harlow, Essex CM202 JE, England.

Rawling, C.A.; and Kolata, R.J. (1983): Cardiopulmonary effects of thiopental lidocaine combination during anaesthesia induction in goats. American journal of Veterinary Research .44(1):144149

Singh, B.; and Kumar, A. (1988): Diazepam as premedication to Thiopentone sodium anaesthesia in goats. Indian Veterinary Journal .65(5): 314-319

Tamisto, T.; Arroma, U. and Koittilla, K. (1981): The role of Thiopentone and fentanyl in production of balanced anaesthesia. Survey of anaesthesia. 25(2): 93-94.

Taylor, P.M. (1990) The stress response to anaesthesia in ponies under barbiturate anaesthesia. Equine veterinary journal. 22(5): 307 $-312$.

Vickers, M.D; Schnieden, H. and Wood-Smith, F.G. (1984): Drugs in anaesthetic practice, six edition, pp25. 
Table 1: Duration (minutes) and percentage (\%) of the different anaesthetic phases in goats following administration of Thiopentone sodium.

\begin{tabular}{|c|c|c|c|c|c|c|c|c|c|c|c|c|}
\hline Phase & Anaestl & & Narco & & $\begin{array}{r}\text { Late } \\
\text { recuml }\end{array}$ & & $\begin{array}{r}\text { Ster } \\
\text { recumb }\end{array}$ & & $\begin{array}{r}\text { Stand } \\
\text { tim }\end{array}$ & & Total rec & very \\
\hline $\begin{array}{c}\text { Proto } \\
\text { col }\end{array}$ & D & $\%$ & D & $\%$ & D & $\%$ & D & $\%$ & $\mathrm{D}$ & $\%$ & $\mathrm{D}$ & $\%$ \\
\hline $\begin{array}{c}\text { Grou } \\
\text { p A }\end{array}$ & $\begin{array}{c}0.85 \pm 0 \\
44^{\mathrm{a}}\end{array}$ & $\begin{array}{c}4.3 \\
1\end{array}$ & $\begin{array}{c}5.05 \pm 3 . \\
47^{\mathrm{a}}\end{array}$ & $\begin{array}{l}24 . \\
52\end{array}$ & $\begin{array}{c}4.63 \pm 0 . \\
93^{\mathrm{a}}\end{array}$ & $\begin{array}{l}22 . \\
53\end{array}$ & $\begin{array}{l}9.67 \pm \\
6.14^{\mathrm{a}}\end{array}$ & $\begin{array}{l}47 . \\
49\end{array}$ & $\begin{array}{c}0.27 \pm 0 \\
.25^{\mathrm{a}}\end{array}$ & $\begin{array}{c}1.3 \\
1\end{array}$ & $\begin{array}{c}20.55 \pm 5 \\
.46^{\mathrm{a}}\end{array}$ & 100 \\
\hline $\begin{array}{c}\text { Grou } \\
\text { p B }\end{array}$ & $\begin{array}{c}11.00 \pm 3 \\
.78^{\mathbf{b}}\end{array}$ & $\begin{array}{c}25 . \\
01\end{array}$ & $\begin{array}{c}12.33 \pm 2 \\
.49^{\mathbf{b}}\end{array}$ & $\begin{array}{c}27 . \\
7\end{array}$ & $\begin{array}{c}11.73 \pm \\
6.69^{\mathrm{a}}\end{array}$ & $\begin{array}{l}25 . \\
69\end{array}$ & $\begin{array}{c}9.33 \pm \\
4.7^{\mathrm{a}}\end{array}$ & $\begin{array}{l}20 . \\
43\end{array}$ & $\begin{array}{c}0.84 \pm 0 \\
.41^{\mathrm{a}}\end{array}$ & $\begin{array}{c}0.8 \\
7\end{array}$ & $\begin{array}{c}45.72 \pm 1 \\
1.99^{\mathbf{b}}\end{array}$ & 100 \\
\hline $\begin{array}{c}\text { Grou } \\
\text { p C }\end{array}$ & $\begin{array}{c}16.66 \pm 5 \\
.52^{\mathrm{b}}\end{array}$ & $\begin{array}{r}29 . \\
4\end{array}$ & $\begin{array}{c}15.72 \pm 3 \\
.67^{\mathbf{b}}\end{array}$ & $\begin{array}{l}27 . \\
74\end{array}$ & $\begin{array}{c}7.74 \pm 3 . \\
67^{\mathrm{a}}\end{array}$ & $\begin{array}{l}13 . \\
66\end{array}$ & $\begin{array}{c}14.66 \pm \\
7.22^{\mathrm{a}}\end{array}$ & $\begin{array}{l}25 . \\
87\end{array}$ & $\begin{array}{c}1.69 \pm 0 \\
.80^{\mathrm{a}}\end{array}$ & $\begin{array}{c}3.3 \\
0\end{array}$ & $\begin{array}{c}56.66 \pm 1 \\
4.04^{\mathbf{b}}\end{array}$ & 100 \\
\hline
\end{tabular}

Different letters in the same column indicates significant difference $(\mathrm{P} \leq 0.05)$

Table 2: Effect of different doses of Thiopentone sodium on respiratory rate.

\begin{tabular}{|c|c|c|c|c|c|c|c|c|}
\hline Dose & Base & zero & 10 & 20 & 30 & 40 & 50 & 60 \\
\hline Group A & $34.47 \pm 16.2 \mathrm{a}$ & $21.85 \pm 7.7 \mathrm{a}$ & $33.75 \pm 11.42 \mathrm{a}$ & $48.66 \pm 8.69 \uparrow \mathrm{b}$ & & & & \\
\hline Group B & $26.66 \pm 3.14 \mathrm{a}$ & $28.66 \pm 3.94 \mathrm{a}$ & $27.16 \pm 10.77 \mathrm{a}$ & $26.16 \pm 11.89 \mathrm{a}$ & $34.8 \pm 15.21 \mathrm{a}$ & $47.7 \pm 13.95 \uparrow \mathrm{b}$ & $48.00 \pm 1.5 \uparrow \mathrm{b}$ & \\
\hline Group C & $30.1 \pm 6.6 \mathrm{a}$ & $15.25 \pm 4.5 \downarrow \mathrm{b}$ & $17.00 \pm 3.42 \downarrow \mathrm{b}$ & $19.00 \pm 3.5 \downarrow \mathrm{b}$ & $18.5 \pm 5.17 \downarrow \mathrm{b}$ & $20.00 \pm 2.9 \mathrm{a}$ & $21.7 \pm 3.0 \mathrm{a}$ & \\
\hline
\end{tabular}

Different letters in the same raw indicates significant difference $(\mathrm{P} \leq 0.05)$ 
Table 3: Effect of different doses of Thiopentone sodium on heart rate.

\begin{tabular}{|l|c|c|c|c|c|c|c|c|}
\hline Dose & Base & zero & 10 & 20 & 30 & 40 & 50 & 60 \\
\hline $\begin{array}{l}\text { Group } \\
\text { A }\end{array}$ & $81.87 \pm 16.00^{\mathrm{a}}$ & $105.75 \pm 15.31^{\mathrm{b}}$ & $124.00 \pm 19.87^{\mathrm{b}}$ & $140.33 \pm 31.3^{\mathrm{b}}$ & & & & \\
\hline $\begin{array}{l}\text { Group } \\
\text { B }\end{array}$ & $100.5 \pm 5.09^{\mathrm{a}}$ & $142.00 \pm 14.37^{\mathrm{b}}$ & $193.83 \pm 56.24^{\mathrm{b}}$ & $182.00 \pm 46.69^{\mathrm{b}}$ & $178.8 \pm 44.74^{\mathrm{b}}$ & $180.5 \pm 59.5^{\mathrm{b}}$ & $103.00 \pm 1.00^{\mathrm{a}}$ & \\
\hline $\begin{array}{l}\text { Group } \\
\text { C }\end{array}$ & $\begin{array}{c}93.37 \pm \\
17.00^{\mathrm{a}}\end{array}$ & $\begin{array}{c}144.00 \pm \\
31.58^{\mathrm{b}}\end{array}$ & $119.12 \pm 9.94^{\mathrm{a}}$ & $131.62 \pm 27.92^{\mathrm{a}}$ & $122.00 \pm 3.9^{\mathrm{a}}$ & $143.2 \pm 9.6^{\mathrm{b}}$ & $104.00 \pm 9.5^{\mathrm{a}}$ & \\
\hline
\end{tabular}

Different letters in the same raw indicates significant difference $(\mathrm{P} \leq 0.05)$

Table 4: Effect of different doses of Thiopentone sodium on rectal temperature

\begin{tabular}{|c|c|c|c|c|c|c|c|c|}
\hline Dose & Base & Zero & 10 & 20 & 30 & 40 & 50 & 60 \\
\hline $\begin{array}{c}\text { Group } \\
\text { A }\end{array}$ & $39.7 \pm 0.54 \mathrm{a}$ & $\begin{array}{c}39.7 \pm 0.55 \\
\mathrm{a}\end{array}$ & $39.6 \pm 0.6 \mathrm{a}$ & $39.5 \pm 0.5 \mathrm{a}$ & & & & \\
\hline $\begin{array}{c}\text { Group } \\
\mathrm{B}\end{array}$ & $\begin{array}{c}39.91 \pm 0.51 \\
\mathrm{a}\end{array}$ & $\begin{array}{c}40.1 \pm 0.25 \\
\mathrm{a}\end{array}$ & $\begin{array}{c}40.05 \pm 0.28 \\
\mathrm{a}\end{array}$ & $\begin{array}{c}40.01 \pm 0.48 \\
\mathrm{a}\end{array}$ & $\begin{array}{c}39.1 \pm 0.56 \\
\mathrm{a}\end{array}$ & $\begin{array}{c}39.47 \pm 0.65 \\
\mathrm{a}\end{array}$ & $\begin{array}{c}39.3 \pm 0.3 \\
\mathrm{a}\end{array}$ & \\
\hline $\begin{array}{c}\text { Group } \\
\text { C }\end{array}$ & $\begin{array}{c}39.5 \pm 0.38 \\
\mathrm{a}\end{array}$ & $\begin{array}{c}39.8 \pm 0.24 \\
\mathrm{a}\end{array}$ & $\begin{array}{c}39.7 \pm 0.37 \\
\mathrm{a}\end{array}$ & $\begin{array}{c}39.6 \pm 0.38 \\
\mathrm{a}\end{array}$ & $\begin{array}{c}39.8 \pm 0.48 \\
\mathrm{a}\end{array}$ & $39.8 \pm 0.6 \mathrm{a}$ & $\begin{array}{c}39.9 \pm 0.5 \\
\mathrm{a}\end{array}$ & \\
\hline
\end{tabular}

Different letters on the same raw indicates significant difference $((\mathrm{P} \leq 0.05)$ 